\title{
Analysis of the Components of Knowledge Management on the Postgraduate IAIN Kendari
}

\author{
Ambar Sri Lestari and Shabrur Rijal Hamka \\ Postgraduate \\ State Islamic Institute of Kendari \\ Southeast Sulawesi, Indonesia \\ ambarlstr@gmail.com
}

\begin{abstract}
This study aims to describe the component analysis of Knowledge Management at Postgraduate IAIN Kendari that includes elements of people, process and technology. This research uses qualitative descriptive method, research respondents are students, Postgraduate lecturer at once Manager IAIN Kendari. Data collection is done by observation, interview and documentation. Data analysis starts from the data collection (data collection), the reduction of data (data reduction), the presentation of data (display data), and the withdrawal of the conclusion (verification of data). The results of the study explained that components of Knowledge Management consist of people, processes, and technology. Component browses on i.e human resources include education, experience, and understanding of the standard operational procedure (SOP), a component of the process include cycle Knowledge Management i.e. socialization, externalization, combination and internalization. In the process of socialization of individuals in organization that is done through face-to-face meetings, discussions and monthly meetings. In the process of externalization of tacit knowledge changes, i.e. knowledge into explicit knowledge is performed by means of document the minutes of meetings or discussions in the form of print and electronic such as minutes of meetings, reports of activities as well as sharing information through the media what's app. In the process of internalization that is a change from explicit knowledge into tacit knowledge through collaboration with several other institutions to build up a more concrete knowledge in the form of activities. And in the process the combination change knowledge from explicit knowledge into explicit knowledge, which is done by doing a working document exchange between employees. In the components of the process also includes a learning organization consists of personal mastery competencies include an individual commitment is accompanied in the organization, shared vision includes openness between individuals in the Organization, mental models include mutually accept and value the opinions of others, system thinking covers the interplay and cooperation within the organization and team learning includes share insights and learn together between individuals and groups in organizations. While the technology components include the means of internet bandwidth capacity that is in the scope of the graduate has divided $16 \mathrm{MB}$ for admin and students by using a fiber optic transmission media and means of such academic information system intranet (SIA) and integrated information system (SIMADU).
\end{abstract}

Keywords- Knowledge Management; People; Process; Technology

\section{INTRODUCTION}

Postgraduate IAIN Kendari is an educational institution that has the authority and duties in the construction and organization of higher education as well as having a role in the efforts of master's degree graduates in the fields of print management of Islamic education, Islamic studies, Islamic law and Islamic Economics in enlightened Nations where one of the knowledge asset is being created so that existing knowledge can be shared on public good through managing knowledge. Advances in technology and an increased knowledge, of course, became a new challenge for a program of study that have to manage their knowledge assets so that it integrates with collaborate and innovate which will encourage the creation of knowledge management, but the most current knowledge it is difficult to be stored in a system due to knowledge more individually only. System training or workshop is running does not have the storage media and the absence of a transfer of knowledge and the training of knowledge management, as a result of staff, students or professors who do not follow the training not knowing the results training and for students not able to take advantage of the knowledge that ought to be known. Tirana [1] conveys that knowledge management is the management of organizational knowledge to create value and generate a competitive advantage or performance. According to the present Raub and Romhardt [2], organization, management of knowledge is actually comprised of eight processes that range from (1) the process of goal setting knowledge (knowledge of the goal), (2) the process of identification, (3) knowledge acquisition process knowledge, (4) the process of knowledge development, (5) the process of sharing and distribution of knowledge, (6) knowledge utilization process (knowledge utilization), (7) maintenance and storage process knowledge (knowledge retention), and (8) process evaluation and measurement of knowledge (knowledge assessment).

But as delivered by Marquardt [3] also McElroy [4] three processes that are the most popular because it most often applied is the process of acquisition of knowledge, the process of knowledge sharing and knowledge utilization process. In field observations showed the management Knowledge Management on existing graduate to date, namely the activity/activities undertaken have not been managed optimally so that haven't understood the knowledge which in scope, Tacit knowledge /Implicit Knowledge and Explicit Knowledge, as 
well as the transfer of knowledge of students through thesis papers also need to be managed properly, so that in the future the concept of knowledge management this can be built into the system in the form of supporting the development of the web as a knowledge management. Based on the literature review as well as the observations made, then the author is interested in analyzing the components of knowledge management that include elements of people, process and technology, so that Knowledge Management as a learning activity organizations can more easily understand what it looks like and how it so that it can support the learning process as well as the development of the organization to the next.

According to Awad [5] stated that knowledge is the understanding gained from experience and learning. Atter, stating that knowledge is a combination of instinct, ideas, rules and procedures that direct action or decision. Information on combining with past experience and expertise will provide a high-value knowledge. So it can be inferred that the knowledge is everything known and acquired through experience and learning that is used as a basis in decision making and action. Because of the importance of knowledge, then needed a good management to manage the knowledge owned by it. As for the knowledge management, according to Fernandez [6] is "Performing the activities involved in discovering, capturing, sharing and applying knowledge so as to enhanced, in a costeffective fashion, the impact of knowledge on the units of the goal achievement, that is the process of performing activities related to finding (discovering), capture (capturing), sharing (sharing), and applied (applying) to improve the knowledge of the implications of knowledge for an achievement of the objectives of an organizational unit.

Martin [7] explained that the knowledge management means the utilization and development of the knowledge assets of an organization to achieve goals, knowledge management is made up of all the processes associated with identifying, sharing and producing knowledge. Described by Turbans [8] that knowledge management is a process that can help the organisation identify, select, organize, disseminate and transfer the important information and expertise, including sections of memory organization and generally were in the organization in a pattern that is not structured. Knowledge management is the active management and of ideas, information and knowledge that belong to individuals. While according to Dalkir [9], Knowledge Management (KM) is a deliberate and systematic coordination of the people in the organization, technology, process, and structure of the Organization, in order to add value through reuse and innovation. This coordination is achieved through the creation, sharing, and applying knowledge, and also throw down the valuable lessons and best practices into the memory of the Organization in order to encourage organizational learning. From some of the above definitions have in common by which it can be concluded that knowledge management, knowledge management processes are organized good catch, discover and disseminate knowledge and use it to achieve the purpose of the organization. Knowledge Management has three components, where each component according to Godbout has a role and a different percentage, namely:

\section{Knowledge Components}

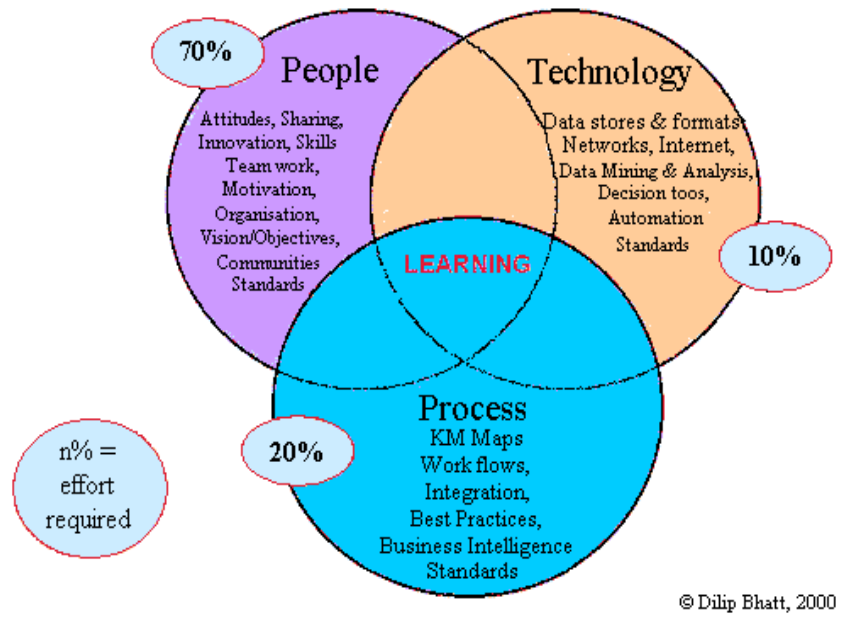

Fig. 1. Knowledge Components

Research associated with the implementation of Knowledge Management, such as that done by the Saini and Ritika [10] posited that in the implementation of the KM required the involvement of top management, organizational culture and infrastructure. As well as the impact of the application of KM for the Organization, as done by Shu-Hsien Liao Chi-Chuan $\mathrm{Wu}$ [11], who argued that knowledge management positively associated with organizational learning. As for the difference of this research with previous studies is that researchers focus on three main components as support Knowledge Management in the postgraduate IAIN Kendari.

\section{METHOD}

This type of research is qualitative research using descriptive methods. With this method will be obtained an overview analysis of the components of Knowledge Management at Postgraduate IAIN Kendari. This research was conducted on Graduate IAIN Kendari. The source of the data in this study there are two primary data is data that is retrieved directly from the researchers on staff, student and lecturer on the postgraduate IAIN Kendari, and secondary data obtained through documentation, journals, reference and research before. The technique of collecting through observation, interview and documentation as well as a Focus Group Discussion (FGD). Data analysis in qualitative research carried out using model Miles Huberman i.e data gathering, data reduction, the presentation of the data and the conclusion.

\section{RESULTS AND DISCUSSION}

\section{A. Findings}

The results of the study explained that components of Knowledge Management consist of people, processes, and technology. Component browses on i.e human resources include education, experience, and understanding of the standard operational procedure (SOP), a component of the process include cycle Knowledge Management i.e. socialization, externalization, combination and internalization. 
In the process of socialization of individuals in your organization that is done through face-to-face meetings such as meetings, discussions and monthly meetings. In the process of externalization of tacit knowledge changes, i.e. knowledge into explicit knowledge is performed by means of document the minutes of meetings or discussions in the form of print and electronic such as minutes of meetings, reports of activities as well as sharing information through the media what's app. In the process of internalization that is a change from explicit knowledge into tacit knowledge through collaboration with several other institutions to build up a more concrete knowledge in the form of activities. And in the process the combination change knowledge from explicit knowledge into explicit knowledge, which is done by doing a working document exchange between employees. In the process component will produce learners Organization (organizational learning) which consists of personal mastery competencies and commitment include individuals in organizations, shared vision includes openness between individuals in the Organization, mental model includes mutual acceptance and respect for others ' opinions, system thinking covers the interplay and cooperation within the Organization and team learning includes share insights and learn together between individuals and groups in organizations. While the technology components include the means of internet bandwidth capacity that is in the scope of the graduate who has 16 MegaBits divided for admin and students by using a fiber optic transmission media and means, such as intranet information system academically (SIA) and the integrated information system (SIMADU).

\section{B. Discussion}

Tobing said [12] that within the Organization, the knowledge obtained from individuals or groups of people who have knowledge. The following were described asset knowledge Graduate IAIN with SECI Model.

$$
\text { Tacit Knowledge to Explicit Knowledge }
$$

\begin{tabular}{|c|c|c|}
\hline $\begin{array}{l}\text { Tacit } \\
\text { Knowledge }\end{array}$ & $\begin{array}{l}\text { Socialisation } \\
\text { - Meeting } \\
\text { - Discussion } \\
\text { Monthly }\end{array}$ & $\begin{array}{l}\text { Externalisation } \\
\text { - Meeting Documents } \\
\text { - Document expert/expert } \\
\text { - Discussion Platform }\end{array}$ \\
\hline From & & \\
\hline $\begin{array}{l}\text { Explicit } \\
\text { Knowledge }\end{array}$ & $\begin{array}{l}\text { Internalisation } \\
\text { - Collaboration } \\
\text { - Cooperation }\end{array}$ & $\begin{array}{l}\text { Combination } \\
\text { - Intranet (SIA, } \\
\text { SIMADU) } \\
\text { - } \quad \text { Internet } 16 \mathrm{MB}\end{array}$ \\
\hline
\end{tabular}

Fig. 2. SECI Model Of Knowledge Conversion Four Process

Knowledge of these existing assets, obtained KM process in the SECI Model are:

1. Analysis of the socialization process between individuals in the Organization, one of which is done through face-to-face meetings (meetings, discussions and monthly meetings).

2. Analysis of the process of externalization of tacit knowledge is a change knowledge into explicit knowledge is done by way of documenting the minutes of meetings or discussions, both print and electronic form in the form of minutes of meetings, reports, activities, as well as the electronic form of sharing information through the media so quick information what's app disseminated to interested parties such as for college students.

3. Analysis of the process of internalization constitutes a change from explicit knowledge into tacit knowledge can be done by means of cooperation to acquire knowledge or information from several other institutions to build the knowledge. More concrete in the form of activities.

4. The analysis of the process of change is a combination of explicit knowledge from knowledge into explicit knowledge, which can be performed by means of document exchange do the work done between employees. So an already documented knowledge through the process of externalization as a result of the meeting, the results of the education or training, back in the sharing or distribution to other co-workers to exchange information or knowledge.

The importance of the role of the knowledge worker in the knowledge management needs to be improved by means of creating a learning organization that consists of: a) organizational learning, organizational learning, i.e. in accordance with the respective level (the level of education and level of academic tenure); b) learning at work that is being done with respect to learning the work (on the job) and c) a learning climate that is the College facilitates learning lecturer so able to create an academic atmosphere is high, such as internet access, subscription journals; and the last d) learning structure that is constantly learning conducted by the organization.

\section{CONCLUSION}

It can be concluded that the component of the knowledge management includes the following three aspects, namely:

1. Aspects of People in Knowledge Management at Postgraduate IAIN Kendari include three things, i.e. education, experience and understanding of standard Operational procedures (SOP). Where education and experience is the most important human resource capital in producing knowledge-knowledge that is thriving and continues to increase as well as an understanding of standard operational procedures also supplement and be a guide or citations of course of all activities and events that take place on a postgraduate IAIN Kendari.

2. Aspects of the process in Knowledge Management at the post-graduate cycle include Kendari IAIN knowledge management, socialization, externalization, combination and internalization. In the process of socialization of individuals organized that is done through face-to-face meetings such as meetings, discussions and monthly meetings. In the process of externalization of tacit knowledge changes, i.e. knowledge into explicit knowledge is performed by means of document the minutes of meetings or discussions in the form of print and electronic such as minutes of meetings, reports of activities as well as sharing media information via what's app. In the process of 
internalization that is a change from explicit knowledge into tacit knowledge through collaboration with several other institutions to build up a more concrete knowledge in the form of activities. And in the process the combination change knowledge from explicit knowledge into explicit knowledge, which is done by doing a working document exchange between employees. In the process component will produce learners Organization (organizational learning) which consists of personal mastery competencies and commitment include individuals in organizations, shared vision includes openness between individuals in the Organization, mental model includes mutual acceptance and respect the opinion of another man, system thinking covers the interplay and cooperation within the Organization and team learning includes share insights and learn together between individuals and groups in organizations.

3. Aspects of technology in Knowledge Management at Postgraduate IAIN Kendari includes facilities/means of internet and intranet. Means of internet bandwidth capacity that is in the scope of the graduate who has 16 MegaBits divided for admin and students by using a fiber optic transmission media and means of such academic information system intranet (SIA) and information systems integrated (SIMADU).

\section{REFERENCES}

[1] Tiwana, Amrit. The Knowledge Management Toolkit: Orchestrating it, Strategy, and Knowledge Platforms 2nd ed. New Jersey: Prentice Hall. 2002.

[2] Probst, Gilbert, Steffen Raub and Kai Romhardt. Managing Knowledge: Building Blocks for Success.West Sussex: John Wiley \& Sons, Ltd. 2000

[3] Marquardt, Michael J. Building The Learning Organization: Mastering the 5 Elements for Corporate Learning 2nd ed. Palo Alto: Davies-Black Publishing. 2002.

[4] McElroy, Mark W. The New Knowledge Management: Complexity, Learning, and Sustainable Innovation. Burlington: ButterworthHeinemann.2002.

[5] Awad EM Ghaziri,H. Knowledge Management. New Jersey:Prentice Hall Inc.2003,h. 45

[6] Fernandez Beccera, Irma, Gonzales, Avelino dan Shaberwal, Rajiv. Knowledge Management: Challengges, Solution and Technologies.New Jersey:Pearson Prentice Hall. 2004,h.105

[7] Matin, E.K. Comparing Degree of Readiness for Implementation ofKnowledge Management in Public and Private Universities in Iran," pp. 623-635, 2012.

[8] Turban E, Sharda, R,. Delen D. Desition Support and Bussiness Intelligence System.New Jersey: Pearson, 2011,h.57

[9] Dalkir, Kimiz. Knowledge Management in Theory and Practice. New York Oxford: Elsevier Butterworth-Heinemann, 2005, p.3

[10] Saini dan Ritika. "Model Development for Key Enablers in the Implementation of Knowledge Management," IUP Journal of Knowledge Management, 11(2), 2013. pp.46-62.

[11] Liao, Shu-hsien, Wu, Chi-chuan. "System Perspective of Knowledge Management, Organizational Learning, and Organizational Innovation, Expert System with Applications. 37, 2010. pp.1096-1103.

[12] [Tobing, Paul L. Knowledge Management Konsep, Arsitektur, dan Implementasi. Graha Ilmu. Yogyakarta, 2007 h.21. 